\title{
Tetrazolium test for viability estimation of Eugenia involucrata DC. and Eugenia pyriformis Cambess. seeds ${ }^{1}$
}

\author{
Fernanda Bernardo Cripa ${ }^{2 *}$, Laura Cristiane Nascimento de Freitas ${ }^{2}$, \\ Andrieli Cristine Grings ${ }^{2}$, Michele Fernanda Bortolini ${ }^{2}$
}

\begin{abstract}
The study aimed to adapt the tetrazolium test methodology to assess the viability of seed of Eugenia involucrata DC. (cherry) and E. pyriformis Cambess. (uvaia) freshly harvested and stored. Three lots of seeds of both species were used, being I (freshly harvested), II (stored for 15 days) and III (stored for 30 days). Seeds (lot I) of both species were immersed in distilled water for 24 hours and submitted to four preparation methods: whole seeds without seed coat and with $3 / 4$ of seed coat; longitudinally cut with and without seed coat (immersed in $0.1 \%$ tetrazolium for 4 hours). The most suitable preparation method was applied to the remaining lots, where three tetrazolium concentrations were tested: $0.075,0.1$ and $0.5 \%$ and three immersion time periods: 2, 4 and 6 hours. The tetrazolium test results were compared to the germination results. For the conduction of the tetrazolium test in seeds of both species we recommend soaking in distilled water by 24 hours and cut lengthwise on seeds with the seed coat. For cherry, the seeds should be immersed in $0.5 \%$ tetrazolium solution for 2 hours. For uvaia seeds, additional studies are recommended.
\end{abstract}

Index terms: viability test, cherry, uvaia, forest species.

\section{Teste de tetrazólio para a estimativa de viabilidade de sementes de Eugenia involucrata DC. e Eugenia pyriformis Cambess.}

\begin{abstract}
RESUMO - O estudo teve como objetivo adequar a metodologia do teste de tetrazólio para avaliar a viabilidade das sementes de Eugenia involucrata DC. (cereja) e E. pyriformis Cambess. (uvaia) recém-colhidas e armazenadas. Foram empregados três lotes de sementes para ambas as espécies, sendo o I (recém-colhidas), II (armazenadas durante 15 dias) e III (armazenadas durante 30 dias). As sementes (lote I) de ambas as espécies, foram imersas em água destilada por 24 horas e submetidas a quatro métodos de preparo: sementes inteiras sem tegumento e com $3 / 4$ do tegumento; sementes cortadas longitudinalmente com tegumento e sem tegumento (imersas em solução de tetrazólio a $0,1 \%$ por $4 \mathrm{~h}$ ). O método de preparo mais adequado foi aplicado aos demais lotes, utilizando-se três concentrações de tetrazólio: 0,075; 0,1 e 0,5\% e três tempos de imersão: 2, 4 e 6 h. Os resultados do teste de tetrazólio foram comparados com os de germinação. Para a condução do teste de tetrazólio em sementes de ambas as espécies recomenda-se a embebição em água destilada por 24 horas e corte longitudinal das sementes com o tegumento. Para cereja, recomenda-se a imersão das sementes em solução de tetrazólio a $0,5 \%$ por 2 horas. Para uvaia, recomendam-se estudos adicionais.
\end{abstract}

Termos para indexação: teste de viabilidade, cereja, uvaia, espécie florestal.

\section{Introduction}

Eugenia involucrata DC. (cherry) and Eugenia pyriformis Cambess. (uvaia) are species that can be used in degraded areas' recovery, being of great importance in the Brazilian flora. E. involucrata, popularly known as cherry is a fruit species that can be found from Minas Gerais to Rio Grande do Sul states, whose fruits ripen from October to December. The E. pyriformis, known as uvaia can be seen from Sao Paulo to
Rio Grande do Sul states and its fruits ripen from September to January (Lorenzi et al., 2006). According to Maluf et al. (2003), Eugenia species have potential for areas' recovery, because of the fauna attraction that acts as a seeds disperser.

Seeds are structures capable of maintaining viability until environmental conditions are favorable for the beginning of a new generation. However, they cannot preserve its vital functions indefinitely (Marcos-Filho, 2005). Therefore, the seeds storage practice management becomes essential to

${ }^{1}$ Submitted on 05/04/2014. Accepted for publication on 07/25/2014.

${ }^{2}$ Pontifícia Universidade Católica do Paraná, Escola de Saúde e Biociências, 85802-532 - Toledo, PR, Brasil.

*Corresponding author $<$ fernandacripa@hotmail.com $>$ 
maintain their physiological quality and ensure the vigor and viability maintenance in the period between sowing and harvest (Azevedo et al., 2003).

The Eugenia species have recalcitrant seeds (Carvalho et al., 2006), sensitive to dehydration, which causes problems in germination as well as storage potential. Therefore, studies on seeds storage are necessary, since the feasibility is under direct influence of time and storage conditions (Fonseca and Freire, 2003). Some studies regarding the seeds storage of Eugenia species have been reproduced to verify the ideal time and storage conditions, as reported by Barbosa et al. (1990); Andrade and Ferreira (2000); Scalon et al. (2004); Delgado and Barbedo (2007); Justo et al. (2007); among others.

The official parameter usually used to evaluate the seeds physiological quality is the germination test, which is performed under controlled conditions, and being ideal for germination (Brasil, 2009). The germination test acts as a support for all the other analyzes (Sena et al., 2010), however, there are some limitations to its conduction, such as the results' delay and their possible modification by fungi presence. Therefore, the development of methods aiming to obtain quick and reliable information of $E$. involucrata and $E$. pyriformis seeds physiological quality may help in decision making regarding their use, as well as, in the viability estimation of stored seeds.

Among tests with fast results, there is the tetrazolium test based on the dehydrogenize enzymes activity that reduces salt at 2,3,5-triphenyl tetrazolium chloride in the seeds living tissues, generating a compound called trifenilformazan of red color and not diffusible, indicating that a respiratory activity exists, and cell and tissues viability (França-Neto et al., 1998). This test can be used to speed up the seed's quality evaluation, allowing decisions making related to the seed management (Pinto et al., 2008).

However, the tetrazolium test methodology is not widespread among forest species, although remaining a good alternative, for many of them has a long germination period, which is a limiting factor for the germination test realization (Fogaça et al., 2011). Given this, the methodology for the tetrazolium test has been studied for several forest species as the Peltophorum dubium (Sprengel) Taubert, (Oliveira et al., 2005) and the Eugenia pleurantha O. Berg. (Masetto et al., 2009), as well as, assessing the seeds' stored quality as the Amburana cearenses (Allemão) A. C. Smith. (Guedes et al., 2010).

Given the above, this study aims to propose a faster method to evaluate Eugenia involucrata DC. and Eugenia pyriformis Cambess. seeds viability, by the tetrazolium test, evaluating the applicability of this test in seeds stored for 15 and 30 days.

\section{Materials and Methods}

The experiment was conducted at the Biotechnology Laboratory of the Pontifical Catholic University of Paraná - Toledo Campus, where Eugenia involucrata DC. fruits (cherry) were used and E. pyriformis Cambess. (uvaia), harvested in October and December 2011, respectively. For both species, the collection was made from five previously selected arrays in the western region of Paraná, Brazil.

The fruits were sent to the laboratory, where they were pulped by friction in a sieve under running water and seeds left to dry in the shade, in laboratory environment for 24 hours. The freshly harvested seeds (lot I) were then separated into different lots according to the storage period: seeds stored for 15 days (lot II) and seeds stored for 30 days (lot III). The storage of lots II and III took place in refrigerator at a temperature around $10{ }^{\circ} \mathrm{C}$, in sealed and drilled polyethylene bags ( 10 holes of approximately $0.5 \mathrm{~mm}$ ) (Barbedo et al., 1998).

For both species the assessment of lot I started with the moisture content determination, using four replicates of $5 \mathrm{~g}$ of seeds, in aluminum containers with known weight, and dried seeds in greenhouse at $105 \pm 3{ }^{\circ} \mathrm{C}$, for 24 hours, according to the methodology of Brasil (2009). For lots II and III of both species the moisture degree was also determined, when using seeds on remaining tests, enabling to verify whether there was seeds moisture loss during storage.

For lot I germination test, for both cherry and uvaia, three different substrates were evaluated, namely: autoclaved sand, three sheets of towel paper and fine vermiculite, arranged in gerbox.

The sand and vermiculite substrates were previously moistened with distilled water until saturation, the towel paper was moistened with distilled water 2.5 times its dry weight (Brasil, 2009).

The seeds of both species underwent disinfection with $2 \%$ sodium hypochlorite for 5 minutes, followed by washing in running water and then placed onto substrates. The test was conducted in a germination chamber (BOD), at a $30^{\circ} \mathrm{C}$ constant temperature and 12 hours photo period (Barbedo et al., 1998).

The germination test evaluation was performed by daily counting of germinated seeds until germination stabilization, which occurred 48 days after sowing. Were considered germinated seeds, those showing primary root equal to or higher than $2.0 \mathrm{~mm}$.

The average germination rate (v), calculated according to Labouriau (1983) was determined. The experimental design was completely randomized with four replications of 25 seeds per experimental unit for each substrate.

The same procedure was performed for stored uvaia 
and cherry seeds lots (lots II and III) once, after 15 and 30 storage days of these lots, the lot I germination test had not yet been completed, making it impossible to indicate the best germination test substrate.

To obtain the germination test results of lot I of both species, the treatments' variances for homogeneity were tested by the Bartlett's test, and those being homogeneous were submitted to the variance analysis ( $\mathrm{F}$ test). The treatments average values were compared using the Tukey test at $5 \%$ probability level to find out what would be the test's best substrate.

Therefore, after determining the most suitable substrate for lot I germination, for each species under study, the same was done to calculate the stored seeds lots average comparison (lots II and III).

Regarding the tetrazolium test, preliminary tests were performed with lot I seeds, both cherry and uvaia, to verify which would have the most appropriate conditions for seeds preparation and staining of both species.

For that purpose, a 24 hours immersion in distilled water was used, followed by the following treatments: whole seeds without seed coat; whole seeds with $3 / 4$ of seed coat; longitudinally cut seeds with seed coat and without seed coat. Each treatment seeds were immersed in $0.1 \%$ tetrazolium for 4 hours at $30^{\circ} \mathrm{C}$ temperature in the dark (Masetto et al., 2009). During each repetition preparation, they were kept immersed in distilled water, until the entire sample was prepared (Brasil, 2009).

After the described above preparations and still using lot I, the distilled water was drained and tetrazolium solution was added at $0.075 ; 0.1$ and $0.5 \%$ concentrations for 2,4 and 6 hours. The seeds were kept in a BOD chamber at $30{ }^{\circ} \mathrm{C}$ in the dark (Brasil, 2009; Masetto et al., 2009). After the immersion time, the seeds were washed in running water and kept submerged in distilled water until the analysis time. After determining the appropriate methodologies for the tetrazolium test for each studied species, these have been applied for the stored seeds lots (lots II and III).

The evaluation was done with a stereoscopic microscope magnification aid $(4 \mathrm{x})$ and the result was expressed in viability percentage, according to the different staining patterns observed in the seeds' internal structures (Masetto et al., 2009).

Regarding the tetrazolium test, the experimental design used was completely randomized in a factorial design $3 \times 3$ (three concentrations and three different immersion periods of seeds in tetrazolium solution), using per experimental unit, four replicates of 25 seeds for each treatment.

The results were submitted initially to the Bartlett test, where treatments variances were tested for homogeneity and those being homogeneous, submitted to the variance analysis ( $\mathrm{F}$ test), and their averages compared using the Tukey test at $5 \%$ probability.
To confirm the tetrazolium test reliability, its result in viability percentage was used for the germination percentages comparison, using a completely randomized design in a factorial $2 \times 3$ (two viability tests, germination test and tetrazolium test, for the three lots at different storage times).

\section{Results and Discussion}

The average speed germination and percentage average results for both species are shown in Table 1. As germination percentage the higher vermiculite and sand substrates averages were observed, being vermiculite $94 \%$ (cherry) and $85 \%$ (uvaia) and sand $83 \%$ (cherry) and $78 \%$ (uvaia), values that did not significantly differ for both species.

Table 1. Germination and average speed germination percentages of Eugenia involucrata DC. (cherry) and Eugenia pyriformis (uvaia) freshly harvested seeds (lot I).

\begin{tabular}{ccccc}
\hline \multirow{2}{*}{ Substrate } & \multicolumn{2}{c}{ Germination (\%) } & \multicolumn{2}{c}{$\begin{array}{c}\text { Average speed } \\
\text { (seeds/days) }\end{array}$} \\
\cline { 2 - 5 } & Cherry & Uvaia & Cherry & Uvaia \\
\hline Sand & $83 \mathrm{ab}^{*}$ & $78 \mathrm{ab}$ & $0.065 \mathrm{a}$ & $0.065 \mathrm{a}$ \\
Paper & $54 \mathrm{~b}$ & $57 \mathrm{~b}$ & $0.072 \mathrm{a}$ & $0.043 \mathrm{~b}$ \\
Vermiculite & $94 \mathrm{a}$ & $85 \mathrm{a}$ & $0.072 \mathrm{a}$ & $0.071 \mathrm{a}$ \\
\hline $\mathrm{CV}(\%)$ & 16.45 & 15.69 & 12.90 & 11.43 \\
\hline
\end{tabular}

*Averages followed by the same letter in the column are not statistically different as per Tukey's test $(\mathrm{p}>0.05)$.

${ }^{1}$ Data transformed by arcsine $\sqrt{\mathrm{X}} / 100$.

A significant difference in germination percentage was observed among vermiculite and paper substrates only, the paper values being inferior compared to the vermiculite ones. The germination average speed values obtained for cherry seeds were statistically the same for the three substrates. Regarding uvaia, the paper substrate significantly differed from the remaining substrates, showing the lowest germination speed ( 0.043 germinated seeds per day).

As for the germination tests performed in laboratory, the most frequently substrates used are sand and paper (Brasil, 2009). However, it was observed that for both cherry and uvaia seeds, the best results were obtained with vermiculite, followed by the sand substrate.

The substrate adopted in lots II and III germination test for both species was vermiculite, which proved to be ideal providing good conditions for the germination test of both tested species. Vermiculite is a substrate commonly used in laboratories for seed germination analysis, presenting advantages such as: easy to get, economic viability, low 
density, chemical composition and particle size uniformity, porosity and water holding capacity (Martins et al., 2012).

The best conditions for the seeds staining preparation was the longitudinal cut realization with or without removing the seed coat, which allowed getting adequate tissue staining of cherry and uvaia seeds.

The main purpose of preconditioning and seed preparation is to facilitate the tetrazolium solution penetration through the tissues (Mendes et al., 2009), therefore, as preconditioning was used in this work, the soaking in distilled water for 24 hours.

Before staining, the seed preparation method with the longitudinal section without removing the seed coat was chosen, once the removal procedure is laborious and time-consuming. It is worth mentioning that results for the longitudinal cut without removing the seed coat were similar to those obtained with the removal, therefore both methods can be used.

Regarding cherry seeds it could be observed that the best results were obtained with 2 hours soaking in $0.5 \%$ tetrazolium solution, with $87 \%$ of viable seeds which was significantly higher than the values obtained in 0.075 and $0.1 \%$ concentrations (Table 2 ).

Table 2. Percentage viability (lot I) of Eugenia involucrata DC. (cherry) and Eugenia pyriformis Cambess. (uvaia) freshly harvested seeds, evaluated by the tetrazolium test solution at different concentrations and coloring times.

\begin{tabular}{|c|c|c|c|c|}
\hline \multicolumn{5}{|c|}{ Eugenia involucrate DC. (cherry) } \\
\hline \multirow[b]{2}{*}{ Concentration } & \multicolumn{3}{|c|}{ Time } & \multirow[b]{2}{*}{ Average } \\
\hline & 2 hours & 4 hours & 6 hours & \\
\hline $0.075 \%$ & $0 \mathrm{Cb}^{*}$ & $30 \mathrm{Ba}$ & $0 \mathrm{Bb}$ & 10 \\
\hline $0.1 \%$ & $57 \mathrm{Ba}$ & $24 \mathrm{Bb}$ & $60 \mathrm{Aa}$ & 47 \\
\hline $0.5 \%$ & $87 \mathrm{Aa}$ & $47 \mathrm{Ab}$ & $8 \mathrm{Bc}$ & 47 \\
\hline Average & 48 & 34 & 23 & \\
\hline CV $(\%)$ & 31.04 & & & \\
\hline \multicolumn{5}{|c|}{ Eugenia pyriformis Cambess. (uvaia) } \\
\hline \multirow[b]{2}{*}{ Concentration } & \multicolumn{3}{|c|}{ Time } & \\
\hline & 2 hours & 4 hours & 6 hours & Average \\
\hline $0.075 \%$ & $0 \mathrm{Ab}^{*}$ & $3 \mathrm{Bb}$ & $49 \mathrm{Ba}$ & 17 \\
\hline $0.1 \%$ & $1 \mathrm{Ab}$ & $6 \mathrm{ABb}$ & $51 \mathrm{Ba}$ & 19 \\
\hline $0.5 \%$ & $9 \mathrm{Ab}$ & $16 \mathrm{Ab}$ & $83 \mathrm{Aa}$ & 36 \\
\hline Average & 3.33 & 8.33 & 61 & \\
\hline CV $(\%)$ & 25.18 & & & \\
\hline
\end{tabular}

*Averages followed by the same uppercase in the column and lowercase in the row do not differ among themselves as per Tukey's test $(p>0.05)$.

It appears that the 4 and 6 hours staining time, the highest viability values were obtained at $0.5 \%(47 \%)$ and $0.1 \%$ $(60 \%)$ concentrations, respectively. However, these values were below the observed at $0.5 \%$ (87\%), which obtained the highest viability of cherry seeds.

For the tetrazolium test, the soaking in $0.5 \%$ for 2 hours was chosen as the best procedure to be adopted in cherry seeds (Table 2), once it allowed maximum viability, a shorter time ( 2 hours), and similar results to the germination in vermiculite (Table 1). To affirm the tetrazolium test reliability, its results should be similar to those obtained with the germination test. Also, at this condition a more homogeneous coloring of the seed internal tissues was observed, facilitating the results' interpretation. Therefore, the tetrazolium concentration and immersion time used on the cherry tests lots II and III (stored seeds) was $0.5 \%$ of tetrazolium solution for 2 hours.

Regarding uvaia seeds, the best results were obtained with 6 hours soaking in $0.5 \%$ tetrazolium concentration ( $83 \%$ of viable seeds), significantly differing from the remaining concentrations, 0.075 and $0.1 \%$ (Table 2). At this concentration $(0.5 \%)$ a significant difference between 2 and 4 hours of soaking in the tetrazolium solution was also found ( 9 and $16 \%$, respectively).

The method applied to uvaia lots II and III (stored seeds) was the seeds soaking in $0.5 \%$ tetrazolium solution for 6 hours, once these conditions provided maximum viability and similar results to germination in vermiculite (84\%) (Table 1).

According to Fogaça et al. (2006), the seeds preparation, the tetrazolium solution concentration and the staining time, are specific to each species. Therefore, after the methodology definition (seeds preparation, tetrazolium concentration and immersion time in the solution), of each studied species, classes of viable and non-viable seeds were established, according to the tissues' staining intensity observed from the whole seed interior.

For cherry seeds, two viable seeds classes and three nonviable seed classes (Figure 1) were established. For uvaia seeds it was not possible to establish feasibility classes, only the distinction between viable and non-viable seeds was made (Figure 2).

To interpret the tetrazolium test, according to FrançaNeto et al. (1998), the analyst must know the seed structures and have experience and capacity for critical judgment. It is important to mention that the uvaia seeds staining were weak (Figure 2), making it difficult to assess them, differently from the cherry seeds situation (Figure 1), demonstrating that the staining pattern can be different for each species and depends primarily on the concentration used. The uvaia seeds weaker staining also indicates greater resistance to the tetrazolium solution penetration for this species, suggesting further studies with higher tetrazolium concentrations, which could aid in the viability classification. 


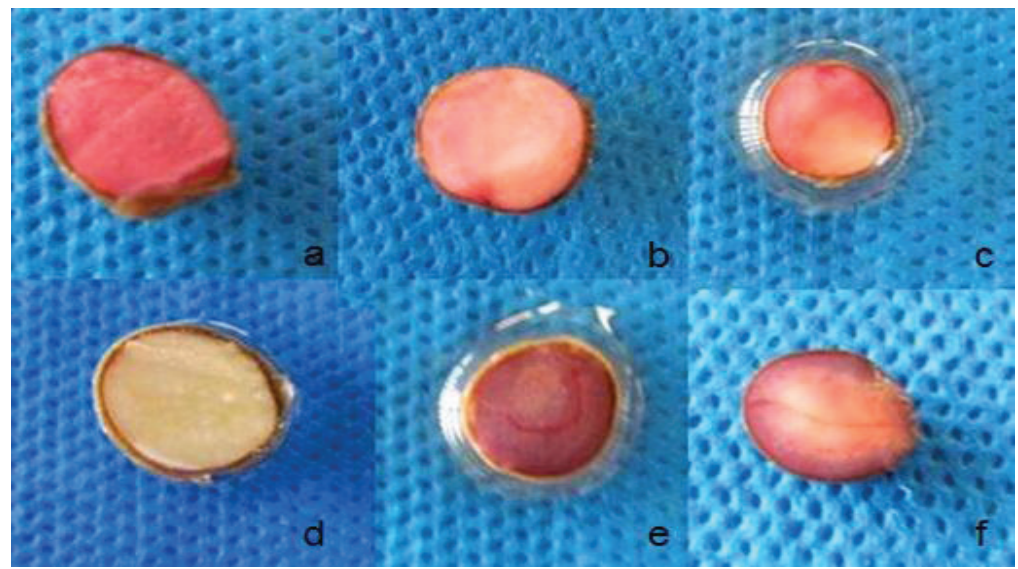

Figure 1. Viability categories found in tetrazolium test of Eugenia involucrata DC. (cherry) seeds. (a and b) viable seeds with homogeneous and firm pinkish; (c) viable seed with pink color in more than $50 \%$ of embryonic tissue; (d) unviable seed with milky white opaque coloration; (e) unviable seed with more than 50\% of embryonic tissue with bright red color; (f) unviable seed with less than $50 \%$ of embryonic tissue with pink color, with edges necrosis and intense red coloration tissue.

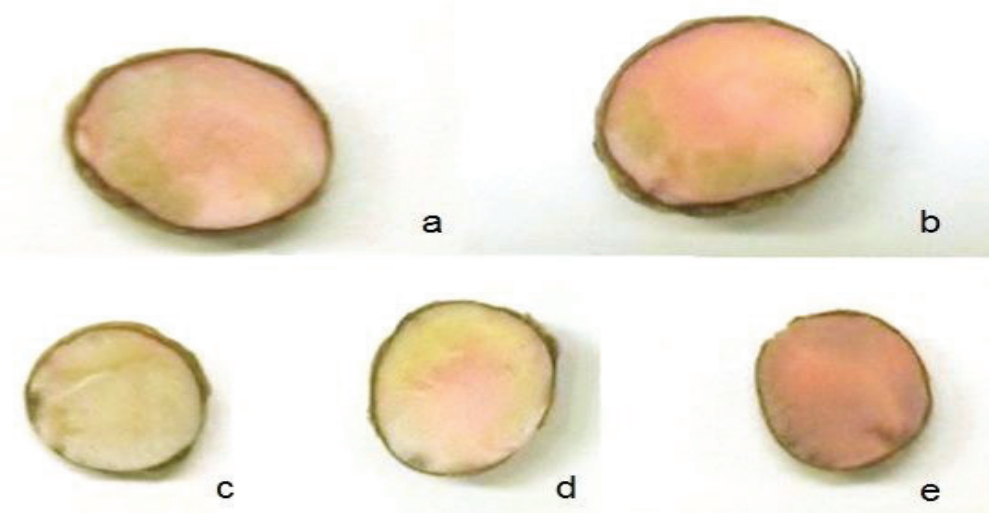

Figure 2. Viability categories found in tetrazolium test of Eugenia pyriformis Cambess. (uvaia) seeds. (a and b) viable seeds with pink color in more than $50 \%$ of embryonic tissue; (c, d, e) unviable seeds.

According to Ferreira et al. (2001), to assess the tetrazolium test reliability, its result must be compared with the germination test result, and obtained viability results should be similar for both. To assess the tetrazolium test reliability for the three lots of both species, the variance analysis was used, in which no significant interaction was found between the test's factors (germination or tetrazolium) and storage time (lots).

Once there was no significant difference between germination and tetrazolium tests in cherry and uvaia seeds, the tetrazolium test applicability was confirmed for the studied species.

For cherry, the general averages values for the three lots showed $83 \%$ of germination and $77 \%$ of viable seeds per the tetrazolium test (Table 3 ). For the cherry seeds storage time, based on the germination and tetrazolium tests results, a higher vigor in lot I was observed (freshly harvested), being significantly larger than lot III only.

Concerning the uvaia seeds storage time, based on the germination and tetrazolium tests results, the higher vigor was observed on freshly harvested seeds (lot I) and stored for 15 days (lot II), which did not significantly differ from each other, but were significantly higher than those stored for 30 days (lot III) (Table 3).

When assessing the cherry and uvaia lots physiological quality, it was found that lots stored for 30 days, showed greater quality loss (Table 3 ). This possibly happened because these are recalcitrant seeds, characteristic that can be observed in the moisture content determination results (Table 4).

It is difficult to identify the specific causes for the intolerance to desiccation in recalcitrant seeds, which can be a result of a combination of factors (Ferreira and Borghetti, 2004). 
Table 3. Average values of the germination and tetrazolium tests on Eugenia involucrata DC. (cherry) and Eugenia pyriformis Cambess. (uvaia) seeds, at different storage time periods.

\begin{tabular}{|c|c|c|c|}
\hline \multicolumn{4}{|c|}{ Eugenia involucrata DC. (cherry) } \\
\hline Storage time period & Germination test (\%) & Tetrazolium test (\%) & Average \\
\hline Lot I (freshly harvested) & 94 & 87 & $90.5 \mathrm{~A}$ \\
\hline Lot II (15 days) & 84 & 76 & $80.0 \mathrm{AB}$ \\
\hline Lot III (30 days) & 72 & 67 & $69.5 \mathrm{~B}$ \\
\hline Average & $83.3 \mathrm{a}^{*}$ & $76.6 \mathrm{a}$ & \\
\hline $\mathrm{CV}(\%)$ & 12.04 & & \\
\hline \multicolumn{4}{|c|}{ Eugenia pyriformis Cambess. (uvaia) } \\
\hline Storage time period & Germination test (\%) & Tetrazolium test (\%) & Average \\
\hline Lot I (freshly harvested) & 85 & 83 & $84.0 \mathrm{~A}$ \\
\hline Lot II (15 days) & 77 & 77 & $77.0 \mathrm{~A}$ \\
\hline Lot III (30 days) & 57 & 50 & $53.5 \mathrm{~B}$ \\
\hline Average & $73.0 \mathrm{a}^{*}$ & $70 \mathrm{a}$ & \\
\hline $\mathrm{CV}(\%)$ & 13.28 & & \\
\hline
\end{tabular}

*Averages followed by the same uppercase in the column and lowercase in the row do not differ among themselves as per Tukey's test ( $p>0.05)$.

Table 4. Moisture content average values of cherry and uvaia seeds at different storage time periods.

\begin{tabular}{lcc}
\hline \multicolumn{1}{c}{ Storage period } & Cherry & Uvaia \\
\hline Lot I (freshly harvested) & $47.4 \%$ & $44.2 \%$ \\
Lot II (15 days) & $46.3 \%$ & $44.0 \%$ \\
Lot III (30 days) & $43.0 \%$ & $43.5 \%$ \\
\hline
\end{tabular}

Even without the complete information on the viability loss cause of recalcitrant seeds, when dehydrated beyond their limits, according to Marcos-Filho (2005), the membrane integrity seems to be the main injuries target. These seeds critical moisture level varies according to the species as per Delgado and Barbedo (2007), the Eugenia seeds losing viability at water contents of 15 to $20 \%$

For Eugenia involucrata lots (cherry) and Eugenia pyriformis (uvaia), high water contents were observed, a characteristic of recalcitrant seeds (Table 4), indicating that there is no desiccation phase at the final development, that they are disconnected from the parent plant with a high water content, being intolerant to desiccation and also to prolonged storage time (Kerbauy, 2008)

Therefore, according to the conditions under which this work was developed, the Eugenia involucrata DC. seeds (cherry) and E. pyriformis Cambess. (uvaia) can be stored for a 15 days period without significant viability loss. Being aware that the germination test for both species took on average 48 days to be finalized and considering that most forest species require a long time to germinate and, that the delay of the germination test implementation is considered a limitation to it (Fogaça et al., 2006), the tetrazolium test is recommended to speed up the decision making regarding the cherry and uvaia seeds use, which are seen as recalcitrant seeds and have a short life time (Scalon et al., 2012).

\section{Conclusions}

The tetrazolium test can be used to evaluate the feasibility of Eugenia involucrata DC. (cherry) and E. pyriformis Cambess. (uvaia) species.

To execute the tetrazolium test, on both species seeds, the soaking in distilled water for 24 hours is recommended, followed by the seed longitudinal cut with the seed coat. For cherry, it is recommended to soak the seeds in $0.5 \%$ tetrazolium solution for 2 hours. For uvaia seeds, the use of this concentration for 6 hours did not allow to obtain an optimal staining pattern in living tissues, indicating the need of additional studies.

\section{Acknowledgements}

To all, who assisted in this work, as well as the Araucaria Foundation, for its financial support.

\section{References}

ANDRADE, R.N.B.; FERREIRA, A.G. Germinação e armazenamento de sementes de uvaia (Eugenia pyriformis Camb.) Myrtaceae. Revista Brasileira de Sementes, v.22, n.2, p.118-125, 2000. http://www.lume.ufrgs.br/bitstream/ handle/10183/23264/000293585.pdf?sequence=1\&locale=pt_BR

AZEVEDO, M.R.Q.A.; GOUVEIA, J.P.G.; TROVÃO, D.M.M.; QUEIROGA, V.P. Influência das embalagens e condições de armazenamento no vigor de sementes de gergelim. Revista Brasileira de Engenharia Agrícola e Ambiental, v.7, n.3, p. 519-524, 2003. http://www.scielo.br/pdf/rbeaa/v7n3/v7n3a19.pdf 
BARBOSA, J.M.; BARBOSA, L.M.; SILVA, T.S.; FERREIRA, D.L. Influência de substratos e temperaturas na germinação de sementes de duas frutíferas silvestres. Revista Brasileira de Sementes, v.12, n.2, p. 66-73, 1990. http://www.abrates.org.br/revista/artigos/1990/v12n2/artigo07.pdf

BARBEDO, C.J.; KOHAMA, S.; MALUF, A.M.; BILIA, D.A.C. Germinação e armazenamento de diásporos de cerejeira (Eugenia involucrata DC. MYRTACEAE) em função do teor de água. Revista Brasileira de Sementes, v.20, n.1, p. 184-188, 1998. http://www.abrates.org.br/revista/artigos/1998/ v20n1/artigo30.pdf

BRASIL. Ministério da Agricultura, Pecuária e Abastecimento. Regras para análise de sementes. Ministério da Agricultura, Pecuária e Abastecimento. Secretaria de Defesa Agropecuária. Brasília: MAPA/ACS, 2009. 395 p. http:// www.agricultura.gov.br/arq editor/file/2946 regras analise sementes.pdf

CARVALHO, L.R.; SILVA, E.A.A.; DAVIDE, A.C. Classificação de sementes florestais quanto ao comportamento no armazenamento. Revista Brasileira de Sementes, v.28, n.2, p. 15-25, 2006. http://www.scielo.br/pdf/ $\mathrm{rbs} / \mathrm{v} 28 \mathrm{n} 2 / \mathrm{a} 03 \mathrm{v} 28 \mathrm{n} 2 . \mathrm{pdf}$

DELGADO, L.F.; BARBEDO, C.J. Tolerância à dessecação de sementes de espécies de Eugenia. Pesquisa Agropecuária Brasileira, v.42, n.2, p. 265272, 2007. http://www.scielo.br/pdf/pab/v42n2/16.pdf

FERREIRA, A.G.; BORGHETTI, F. Germinação: do básico ao aplicado. Porto Alegre: Artmed, 2004. 323 p.

FERREIRA, R.A.; VIEIRA, M.G.G.C.; VON PINHO, E.V.R.; TONETTI, O.A.O. Morfologia da semente e de plântulas e avaliação da viabilidade da semente de sucupira-branca (Pterodon pubescens Benth. - Fabaceae) pelo teste de tetrazólio. Revista Brasileira de Sementes, v.23, n.1, p. 108-115, 2001. http://www.abrates.org.br/revista/artigos/2001/v23n1/artigo15.pdf

FOGAÇA, C.A.; MALAVASI, M.M.; ZUCARELI, C.; MALAVASI, U.C. Aplicação do teste de tetrazólio em sementes de Gleditschia amorphoides Taub. Caesalpinaceae. Revista Brasileira de Sementes, v.28, n.3, p. 101-107, 2006. http://www.scielo.br/pdf/rbs/v28n3/15.pdf

FOGAÇA, C.A.; KROHN, N.G.; SOUZA, M.A.; PAULA, R.C. Teste de tetrazólio em sementes de Copaifera langsdorffi e Schizolobium parahyba. Floresta, v.41, n.4, p. 895 - 904, 2011. http://ojs.c3sl.ufpr.br/ojs/index.php/ floresta/article/viewArticle/25352

FONSECA, S.C.L.; FREIRE, H.B. Sementes recalcitrantes: problemas na pós-colheita. Bragantia, v.62, n.2, p.297-303, 2003. http://www.scielo.br/ $\mathrm{pdf} / \mathrm{brag} / \mathrm{v} 62 \mathrm{n} 2 / \mathrm{v} 62 \mathrm{n} 2 \mathrm{a} 16 . \mathrm{pdf}$

FRANÇA-NETO, J.B.; KRZYZANOWSKI, F.C.; COSTA, N.P. $O$ teste de tetrazólio em sementes de soja. Londrina: EMBRAPA-CNPSo, 1998, 72 p. (Documentos, 116).

GUEDES, R.B.; ALVES, E.U.; GONÇALVES, E.P.; VIANA, J.S.; FRANÇA, P.R.C.; SANTOS, S.S. Qualidade fisiológica de sementes armazenadas de Amburana cearensis (Allemão) A. C. Smith. Semina: Ciências Agrárias, v.31, n.2, p. 331-342, 2010. http://www.uel.br/revistas/uel/index.php/ semagrarias/article/view/5296/4822

JUSTO, C.F.; ALVARENGA, A.A.; ALVES, E.; GUIMARÃES，R.M.; STRASSBURG, R.C. Efeito da secagem, do armazenamento e da germinação sobre a micromorfologia de sementes de Eugenia pyriformis Camb. Revista Acta Botanica Brasilica, v.21, n.3, p.539-551, 2007. http://www.scielo.br/ $\mathrm{pdf} / \mathrm{abb} / \mathrm{v} 2 \ln 3 / \mathrm{a} 04 \mathrm{v} 21 \mathrm{n} 3 . \mathrm{pdf}$
KERBAUY, G.B. Fisiologia Vegetal. Rio de Janeiro: Editora Guanabara Koogan S.A., 2008. 431p.

LABOURIAU, L.G. A germinação de sementes. Washington: Organização dos Estados Americanos, 1983. 174p

LORENZI, H.; BACHER, L.; LACERDA, M.; SARTORI, S. Frutas brasileiras e exóticas cultivadas: de consumo in natura. Nova Odessa: Plantarum, 2006. p.198-199.

MALUF, A.M.; BILIA, D.A.C.; BARBEDO, C.J. Drying and storage of Eugenia involucrata DC. seeds. Scientia Agricola, v.60, n.3, p. 471-475, 2003. http://www.scielo.br/pdf/sa/v60n3/16400.pdf

MARCOS-FILHO, J. Fisiologia de sementes de plantas cultivadas. Piracicaba: FEALQ, 2005. 495p

MARTINS, C.C.; MACHADO, C.G.; SANTANA, D.G.; ZUCARELI, C. Vermiculita como substrato para o teste de germinação de sementes de ipêamarelo. Semina: Ciências Agrárias, v.33, n.2, p. 533-540, 2012. http://www. uel.br/revistas/uel/index.php/semagrarias/article/view/6370/10443

MASETTO, T.E.; DAVIDE, A.C.; FARIA, J.M.R.; SILVA, E.A.A.; REZENDE, R.K.S. Avaliação da qualidade de sementes de Eugenia pleurantha (MYRTACEAE) pelos testes de germinação e tetrazólio. Agrarian, v.2, n.5, p. 34-46, 2009. http://www.periodicos.ufgd.edu.br/index. php/agrarian/article/viewArticle/802

MENDES, A.M.S.; BASTOS, A.A.; MELO, M.G.G. Padronização do teste de tetrazólio em sementes de Parkia velutina Benoist (Leguminosae Mimosoideae). Acta Amazônica, v.39, n.4, p. 823-828, 2009. http://www. scielo.br/pdf/aa/v39n4/v39n4a10.pdf

OLIVEIRA L.M.; CARVALHO, M.L.M.; DAVIDE, A.C. Teste de tetrazólio para avaliação da qualidade de sementes de Peltophorum dubium (Sprengel) Taubert - Leguminosae Caesalpinioideae. Cerne, v.11, n.2, p. 159-166, 2005. http://www.dcf.ufla.br/cerne/artigos/11-02-20097975v11_n2_artigo\%2006.pdf

PINTO, T.L.F.; BRANCALION, P.H.S.; NOVEMBRE, A.D.L.C.; CICERO, S.M. Avaliação da viabilidade de sementes de coração-de-negro (Poecilanthe parviflora Benth. - Fabaceae-Faboideae) pelo teste de tetrazólio. Revista Brasileira de Sementes, v.30, n.1, p.208-214, 2008. http://www.scielo.br/pdf/ $\mathrm{rbs} / \mathrm{v} 30 \mathrm{n} 1 / \mathrm{a} 26 \mathrm{v} 30 \mathrm{n} 1 . \mathrm{pdf}$

SCALON, S.P.Q.; NEVES, E.M.S.; MASETTO, T.E.; PEREIRA, Z.V Sensibilidade à dessecação e ao armazenamento em sementes de Eugenia pyriformis Cambess. (uvaia). Revista Brasileira de Fruticultura, v.34, n.1, p.269-276, 2012. http://www.scielo.br/pdf/rbf/v34n1/v34n1a36.pdf

SCALON, S.P.Q.; SCALON FILHO, H; RIGONI, M.R. Armazenamento e germinação de sementes de uvaia Eugenia uvalha Cambess. Ciência e Agrotecnologia, v.28, n.6, p.1228-1234, 2004. http://www.scielo.br/pdf/ cagro/v28n6/a02v28n6.pdf

SENA, L.H.M.; MATOS, V.P.; FERREIRA, E.G.B.S.; SALES, A.G.F.A.; PACHECO, M.V. Qualidade fisiológica de sementes de pitangueira submetidas a diferentes procedimentos de secagem e substratos - Parte 1 . Revista Brasileira de Engenharia Agrícola e Ambiental, v.14, n.4, p.405-411, 2010. http://www.scielo.br/pdf/rbeaa/v14n4/v14n04a09.pdf 